\title{
THE NOVEL MODELING APPROACH FOR STUDYING THE THERMAL DEGRADATION OF PMMA/NANOOXIDE SYSTEMS
}

\author{
Mirjana Jovičić ${ }^{1}$, Oskar Bera ${ }^{1}$, Katalin Mészáros Szécsényi ${ }^{2}$, Predrag Kojić1, \\ Jaroslava Budinski-Simendić ${ }^{1}$, Dragan Govedarica ${ }^{1}$, Jelena Pavličević ${ }^{1 *}$ \\ ${ }^{1}$ University of Novi Sad, Faculty of Technology, Blvd. Cara Lazara 1, 21000 Novi Sad, Serbia \\ ${ }^{2}$ University of Novi Sad, Faculty of Sciences, Trg Dositeja Obradovića 3, 21000 Novi Sad, Serbia \\ jpavlicevic@uns.ac.rs
}

PMMA (poly(methyl methacrylate)) nanocomposites differing in their nature, size, and surface area were prepared containing one volume percent of silica, alumina or titania. These samples and pure PMMA were prepared in order to analyze how the presence of nanooxides affects the thermal stability and degradation kinetics of the materials. A detailed study of thermal degradation and thermal changes was performed by Simultaneous Thermogravimetry and Differential Scanning Calorimetry (SDT). The proposed mathematical model, including all three heating rates in one minimizing function, well fitted all TGA data obtained with a very high coefficient of correlation. This enabled an assessment of four decomposition steps of the PMMA samples and a calculation of their activation energies and individual contributions to total mass loss. The addition of the largest nanoparticles (titania) caused the highest activation energy for each DTG stage of the PMMA/nanooxide systems. The enhancement of head-to-head $\mathrm{H}-\mathrm{H}$ bonding strength was achieved by addition of alumina and titania. The influence of the size and nature of nanoparticles on the glass transition temperature of prepared PMMA systems was also determined.

Keywords: PMMA/nanooxide system; mathematical modeling; thermal stability; DSC; thermal decomposition kinetics

\section{НОВ ПРИОД КОН МОДЕЛИЕРАЊЕ ИСПИТУВАЊЕ НА ТЕРМИЧКОТО РАЗЛОЖУВАЊЕ НА РММА/НАНООКСИДНИ СИСТЕМИ}

Синтетизирани се нанокомпозити на РММА (поли(метилметакрилат)) што содржат силициум диоксид, алуминиум оксид и титаниум диоксид, а се разликуваат по нивната природа, големина и површина. Овие примероци и чист РММА беа приготвени со цел да се испита како присуството на наноксидите влијае врз термичката стабилност и кинетиката на разложување на овие материјали. Извршено е детално испитување на термичкото разложување и термички промени со помош на симултаната термогравиметрија и диференцјалната скенирачка колоримертрија (SDT). Предложениот математички модел, вклучувајќи ги трите брзини на загревање во една минимизирана функција, покажа добра усогласеност со висок степен на корелација со добиените податоци за TGA. Ова овозможи добра процена на четирите чекори на разложување на примероците на РММА и пресметка на нивните енергии на активација и на индивидуалниот придонес во вкупната загуба на маса. Додавањето на најголемите наночестички (титаниум диоксид) предизвикува највисока енергија на активација за секој степен на DTG на системите на PMМА/нанооксид. Засилувањето на сврзување на силата Н-H чело-на-чело се постигнува со додавање на алуминиум оксид и титаниум оксид. Определено е и влијанието на големината и природата на наночестичките врз температурата на преминот во стакло на подготвените системи на РММА.

Клучни зборови: систем на РММА/нанооксид; математичко моделирање; термичка стабилност; DSC; кинетика на термичко разложување 


\section{INTRODUCTION}

Poly(methyl methacrylate) (PMMA) is a widely used amorphous thermoplastic polymer with good mechanical properties, high impact resistance, dimensional stability and transparency [1-4]. PMMA materials have found various applications in the field of optics, microelectronics, food packaging, medicine, dentistry, cosmetics, and others. However, the wide range of PMMA usage is influenced by low thermal stability for high temperature applications $[5,6]$.

In the recent past, many research studies have attempted to improve thermal stability and to design optimal end-use properties of PMMA by adding different fillers (organoclays, alumina, silica, titania, zinc oxide, zirconium oxide and iron oxide) into the low viscosity monomers [7-9]. Different effects of various inorganic additives on the thermal stability and degradation of PMMA were assessed. Namely, some investigations showed that the thermal decomposition of PMMA loaded with silica nanoparticles was similar to PMMA or it was even deteriorated by the presence of $\mathrm{SiO}_{2}$ [10-12]. On the other hand, it was found that the presence of silica retarded the thermal decomposition of the polymer chains, which is explained by the large silica surface area, radicals trapped by silica during degradation, and by uncondensed residue of the precursor which needed a large amount of heat to decompose [13]. The addition of titania enhanced thermo-oxidative degradation of PMMA nanosystems; while no obvious influence on thermal stability and decomposition of PMMA composites was detected in the presence of zirconium oxide particles [14]. Furthermore, a remarkable enhancement of thermal stability by about $50 \mathrm{~K}$ was registered for PMMA modified with the combination of iron and titanium oxide at $5 \%$ of mass fraction $[15,16]$. It was also found that the addition of alumina significantly increased the decomposition temperature of PMMA by about $20 \mathrm{~K}$, as registered by a TG method [17].

Since PMMA applications in high temperature environments are limited by its low thermal stability, from fundamental and technological aspects, it is very important to study the thermal decomposition of modified PMMA materials to obtain information necessary to predict the mechanism of the decomposition. Many reports can be found in the literature, dedicated to detailed investigations of the thermal stability and degradation of the pure PMMA and its composites. Various methods and atmospheres (air, nitrogen, oxygen, argon and helium) have been used for these studies [18-
22]. However, thermogravimetry (TG) has been shown to be the most useful tool for analyzing the different thermal degradation processes of PMMA materials and their hybrids by kinetic calculations.

Many factors, including the nature and physical properties of polymer, weak linkages and the nature of end groups, affect the thermal degradation mechanism of PMMA [19]. Numerous studies have reported different numbers of TG stages detected (three or four) [23-25]. Additionally, the presence of different average particle sizes of the distributed nanoparticles has different influences on the thermal stability of the PMMA composites as well as on their degradation mechanism and kinetics. This has been investigated using various mathematical models.

In this work, a series of PMMA nanocomposites were obtained by free radical bulk polymerization with the addition of low amounts of alumina, titania or silica $(1 \mathrm{vol} \%)$. The influence of the nanoparticles' type (hydrophilic or hydrophobic) on the thermal stability and degradation of the prepared materials was investigated using simultaneous thermogravimetry - differential scanning calorimetry (SDT) at three heating rates $(5,10$ and 20 $\mathrm{K} / \mathrm{min}$ ). On the basis of the TG data obtained, the effect of inorganic nanoparticles on the onset temperature and maximum degradation temperatures was determined. The main goal of the work was to develop the most suitable mathematical model for fitting TGA data that includes all three heating rates in one minimizing function, enabling the calculation of parameters of the thermal decomposition kinetics of new PMMA materials.

\section{EXPERIMENTAL PART}

\subsection{Materials}

Before polymerization, methyl methacrylate (MMA), obtained from Sigma Aldrich, was washed with a $10 \%$ aqueous $\mathrm{NaOH}$ solution, dried over anhydrous $\mathrm{CaCl}_{2}$, and distilled in a nitrogen atmosphere under the reduced pressure. As a polymerization initiator, 2,2'-azobis(2-methylpropionitrile) (AIBN, p.a., Sigma Aldrich), previously recrystallized from methanol, was used. A series of PMMA hybrid materials were obtained using $1 \%$ volume fraction of different hydrophilic (Aerosil 380, AeroxideAlu C, and Aeroxide PF2) or hydrophobic (Aerosil R812, AeroxideAlu C 805 and Aeroxide T805) nanoparticles. All of these were purchased from Evonik. According to producer's data for the nanoparticles used, Aerosil 380 is a hydrophilic fumed silica with a high specific 
surface area, while Aerosil R812 is a fumed silica post-treated with organosilane (HMDS) with a high specific surface area and marked hydrophobia. Aeroxide Alu $\mathrm{C}$ is a fine-particulate pure aluminum oxide with high specific surface area and a marked aggregate and agglomerate structure. Aeroxide Alu C 805 is a very fine pyrogenic aluminum oxide treated with octylsilane. Furthermore, Aerooxide PF2 is a highly dispersed titanium dioxide that is manufactured according to an AEROSIL process, and it is based on a mixture of titania and iron oxide. Aeroxide T 805 is a fineparticulate fumed titanium dioxide that is highly hydrophobized with an organosilane. Based on the supplier's data, the hydrophilic nanoparticles contain $2.5-8$ hydroxyl groups per $1 \mathrm{~nm}$. The specifications for the nanoparticles used are summarized in Table 1. Before use, they were dried in vacuum during $24 \mathrm{~h}$ at $383 \mathrm{~K}$.

\subsection{PMMA preparation procedure}

PMMA and six PMMA nanocomposite samples were prepared in the following way. In the first step, $1 \%$ (mass fraction) of initiator AIBN, calculated on the basis of methyl methacrylate, was added to the monomer. Six samples containing a $1 \%$ volume fraction of uniformly dispersed inorganic fillers in a MMA/AIBN mixture were obtained by stirring for $2 \mathrm{~h}$ with a magnetic stirrer (at room temperature) then in ultrasonic bath for $15 \mathrm{~min}$. The final mixture was put into molds, and the bulk polymerization was performed in an oven at $343 \mathrm{~K}$ for $90 \mathrm{~min}$. The polymerization conditions were chosen on the basis of previously reported results concerning the impact of oxide nanoparticles on the kinetics of free radical bulk methyl methacrylate polymerization [26]. The codes of the samples, depending on the nanoparticles type, are given in Table 1.

Table 1

The codes of pure PMMA and prepared PMMA hybrid materials as well as the specifications of the used nanoparticles

\begin{tabular}{|c|c|c|c|c|c|}
\hline \multirow[b]{2}{*}{ Sample code } & \multirow[b]{2}{*}{$\begin{array}{l}\text { Particle; } \\
\text { commercial name }\end{array}$} & \multirow[b]{2}{*}{ Nature } & \multicolumn{3}{|c|}{ Specification } \\
\hline & & & $\begin{array}{c}\text { Average } \\
\text { diameter } \\
d(\mathrm{~nm})\end{array}$ & $\begin{array}{c}\text { Specific } \\
\text { surface area } \\
\text { BET }\left(\mathrm{m}^{2} / \mathrm{g}\right)\end{array}$ & $\begin{array}{c}\text { Density } \\
\rho\left(\mathrm{g} / \mathrm{cm}^{3}\right)\end{array}$ \\
\hline PMMA-0 & - & - & - & - & - \\
\hline PMMA-Si-OH & $\begin{array}{l}\mathrm{SiO}_{2} \\
\text { Aerosil 380; }\end{array}$ & hydrophilic & 7 & $380 \pm 30$ & 2.2 \\
\hline PMMA-Si-R & $\begin{array}{l}\mathrm{SiO}_{2} \\
\mathrm{R} 812\end{array}$ & hydrophobic & 7 & $260 \pm 30$ & 2.2 \\
\hline PMMA-Al-OH & $\begin{array}{l}\mathrm{Al}_{2} \mathrm{O}_{3} \\
\text { AeroxideAlu C }\end{array}$ & hydrophilic & 13 & $100 \pm 15$ & 3.987 \\
\hline PMMA-Al-R & $\begin{array}{l}\mathrm{Al}_{2} \mathrm{O}_{3} \\
\text { AeroxideAlu C } 805\end{array}$ & hydrophobic & 13 & $100 \pm 15$ & 3.987 \\
\hline PMMA-Ti-OH & $\begin{array}{l}\mathrm{TiO}_{2} \\
\text { Aeroxide PF2 }\end{array}$ & hydrophilic & 20 & $45 \pm 10$ & 4.23 \\
\hline PMMA-Ti-R & $\begin{array}{l}\mathrm{TiO}_{2} ; \\
\text { Aeroxide } \mathrm{T} 805\end{array}$ & hydrophobic & 20 & $57.5 \pm 12.5$ & 4.23 \\
\hline
\end{tabular}

\subsection{Thermogravimetry coupled with differential scanning calorimetry (TG-DSC analysis)}

The thermal degradation of the prepared materials was studied by simultaneous TG/DSC measurements using TA Instruments SDT Q600 thermal analyzer. The measurements were done in the temperature range from 303 to $773 \mathrm{~K}$ at three different heating rates $(5,10$ and $20 \mathrm{~K} / \mathrm{min})$ in nitrogen atmosphere with a flow rate of $100 \mathrm{~cm}^{3} / \mathrm{min}$. The sample masses were about $5 \mathrm{mg}$. All experiments were performed using an open alumina crucible and a corresponding empty referent crucible.

\section{RESULTS AND DISCUSSION}

A detailed analysis of the thermogravimetric data for the degradation of PMMA and the influence of the nanoparticles on the thermal stability allows an investigation of adequate material design which will enable the assessment of optimal conditions for PMMA processing and to increase its thermal stability [27]. Figure 1 presents simultaneous TG/DTG and DSC curves of pure PMMA, while separate TG, DTG, and DSC curves of synthesized PMMA nanocomposites are displayed in Figures 2a, 2b, and 2c, respectively. From the 
TG/DTG curves (Fig. 1) it can be seen that PMMA is thermally stable up to onset temperature, $T_{\text {onset }}=$ $439 \mathrm{~K}$, with a small mass loss of about $2 \%$. All synthesized unfilled and filled PMMA samples undergo almost complete thermal degradation at $750 \mathrm{~K}$ with a very small registered char residue of about $1.5 \%$ (Figs. 1 and 2a). The shape of the TG curves indicates that the thermal degradation of neat PMMA and the synthesized nanocomposites is a stepwise process, where the effect of the inorganic nanofillers on the TG profiles is assessed. For all investigated PMMA samples, four TG steps were detected which is in accordance with literature data [24] (e.g. for neat PMMA, mass losses connected with four TG stages are $2 \%, 18 \%, 30 \%$ and $50 \%$, respectively).

From DSC curves of neat PMMA (Fig. 1) and its nanocomposites, given in Figure 2c, the glass transition temperatures, $T_{\mathrm{g}}$, are detected in the temperature interval between 310 and $390 \mathrm{~K}$, which is expected, and it is in accordance with our previous investigation [26]. The glass transition temperatures determined for pure PMMA and the prepared hybrid materials are shifted to lower values by about $5 \mathrm{~K}$ when compared with $T_{\mathrm{g}}$ values of the same PMMA systems in reference [26]. This can be explained by the lower sensitivity of the simultaneous TG/DTG and DSC TA Instruments SDT Q600 used in regard to TA Instruments Q20 thermal analyzer. On the basis of the glass transition temperature determined for prepared PMMA nanosystems, it can be seen that the $T_{\mathrm{g}}$ value is affected by the type of oxide particles used (their size and nature). Namely, an increase of the nanoparticles' size caused higher $T_{\mathrm{g}}$ (the highest $T_{\mathrm{g}}$ value was registered at $378 \mathrm{~K}$ for PMMA-Ti-OH). From the DSC curves in the temperature range above, it was also confirmed that the glass transition temperature of hybrid materials modified with hydrophilic inorganic additives is always higher than that of hybrid materials filled with hydrophobic nanoparticles. The lowest increase of $T_{\mathrm{g}}$ was found for the PMMA-Si-OH sample, which indicated that there was no improvement of head-to-head $\mathrm{H}-\mathrm{H}$ bonding by the addition of hydrophilic silica.

The endothermic events associated with the decomposition steps of neat PMMA and PMMA nanosystems are registered from 450 to $670 \mathrm{~K}$ in DSC curves. The last stage of the oxidation $\left(T_{\max }=\right.$ $673 \mathrm{~K}$ ) is due to the presence of oxygen atoms in the PMMA structure.

The characteristic temperatures of the DTG profiles for unfilled and filled PMMA (at three heating rates) are obtained by detailed inspection of DTG curves and are summarized in Table 2. The first DTG maximum peak for all investigated samples (detected in the temperature range from 441 to $470 \mathrm{~K}$ at heating rate of $10 \mathrm{~K} / \mathrm{min}$ ) corresponds to the first degradation step initiated by radical transfer to the unsaturated chain ends [25] or the unreacted MMA monomers trapped inside of the polymer, and it matches with a mass loss of $2 \%$. The homolytic scission of the chain due to head-to-head $\mathrm{H}-\mathrm{H}$ bonding and the thermal decomposition induced by random scission of PMMA main chains [28] are ascribed to the second and the third DTG peaks with maxima registered in the temperature ranges from 530 to $595 \mathrm{~K}$ and from 563 to $570 \mathrm{~K}$ (at heating rate of $10 \mathrm{~K} / \mathrm{min}$ ), respectively. The fourth change noticed in the last part of the DTG curve above $573 \mathrm{~K}$ with a maximum from 653 to $663 \mathrm{~K}$ is assigned to the complete destruction of the remaining part of the polymer.

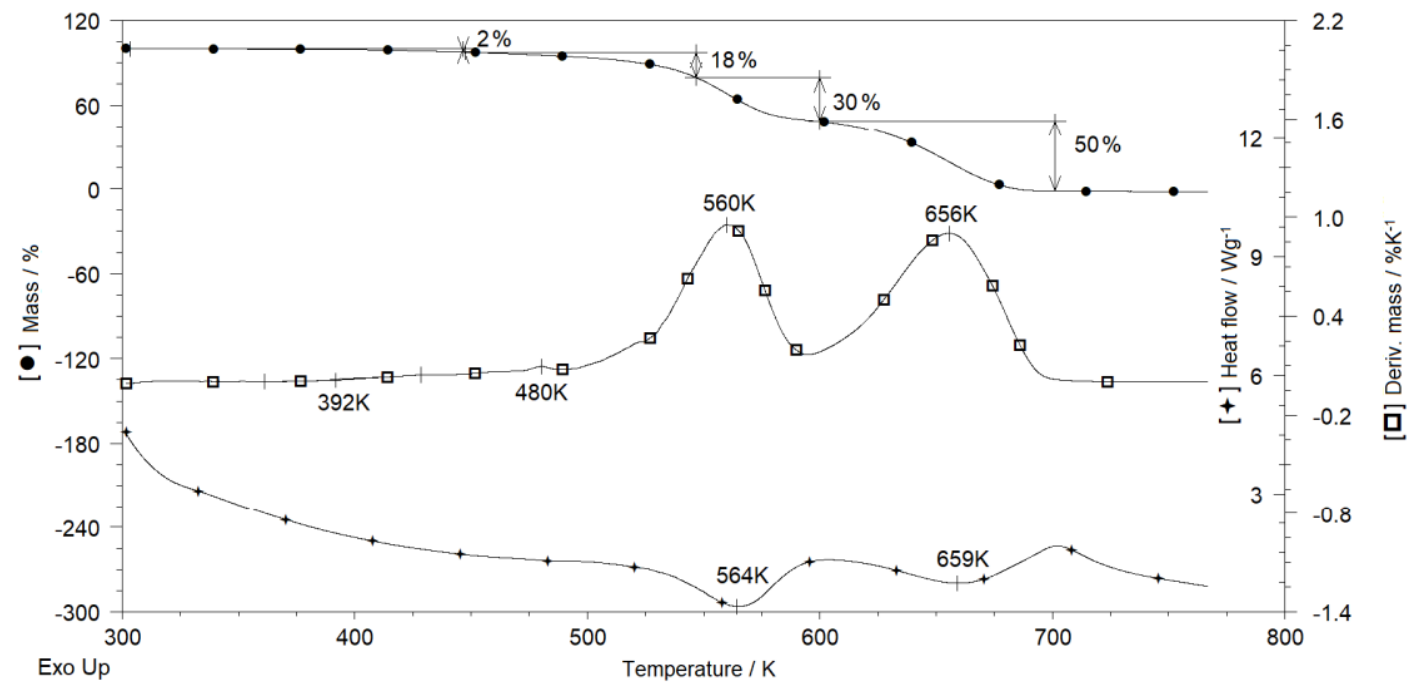

Fig. 1. The simultaneous TG, DTG and DSC curves of pure PMMA. The heating rate was $10 \mathrm{~K} / \mathrm{min}$. 

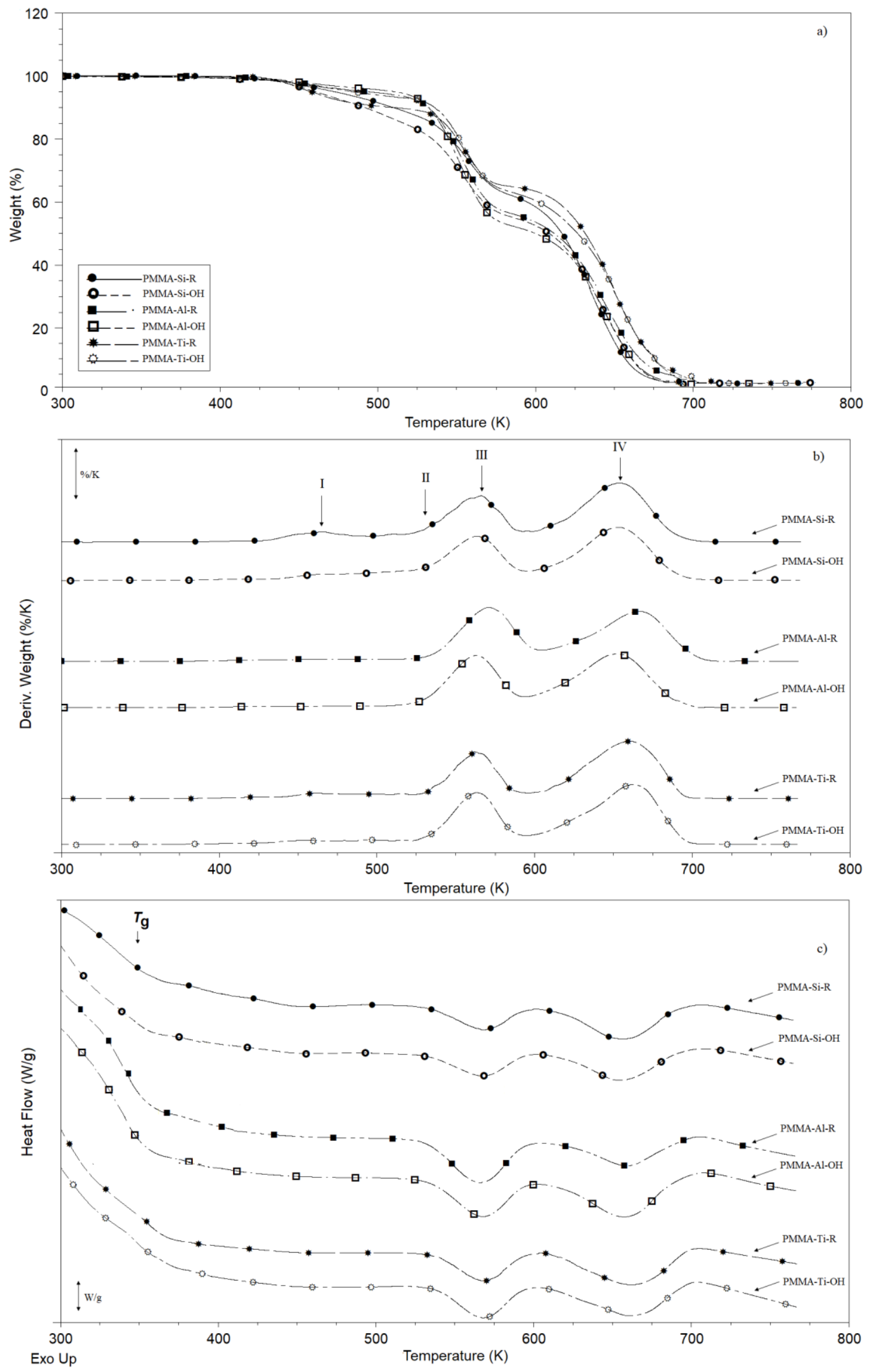

Fig. 2. a) TG, b) DTG, and c) DSC curves of synthesized PMMA nanocomposites. The heating rate was $10 \mathrm{~K} / \mathrm{min}$. 
Table 2

The maximum temperature of four stages observed in DTG curves, obtained at three heating rates, for unfilled and filled PMMA

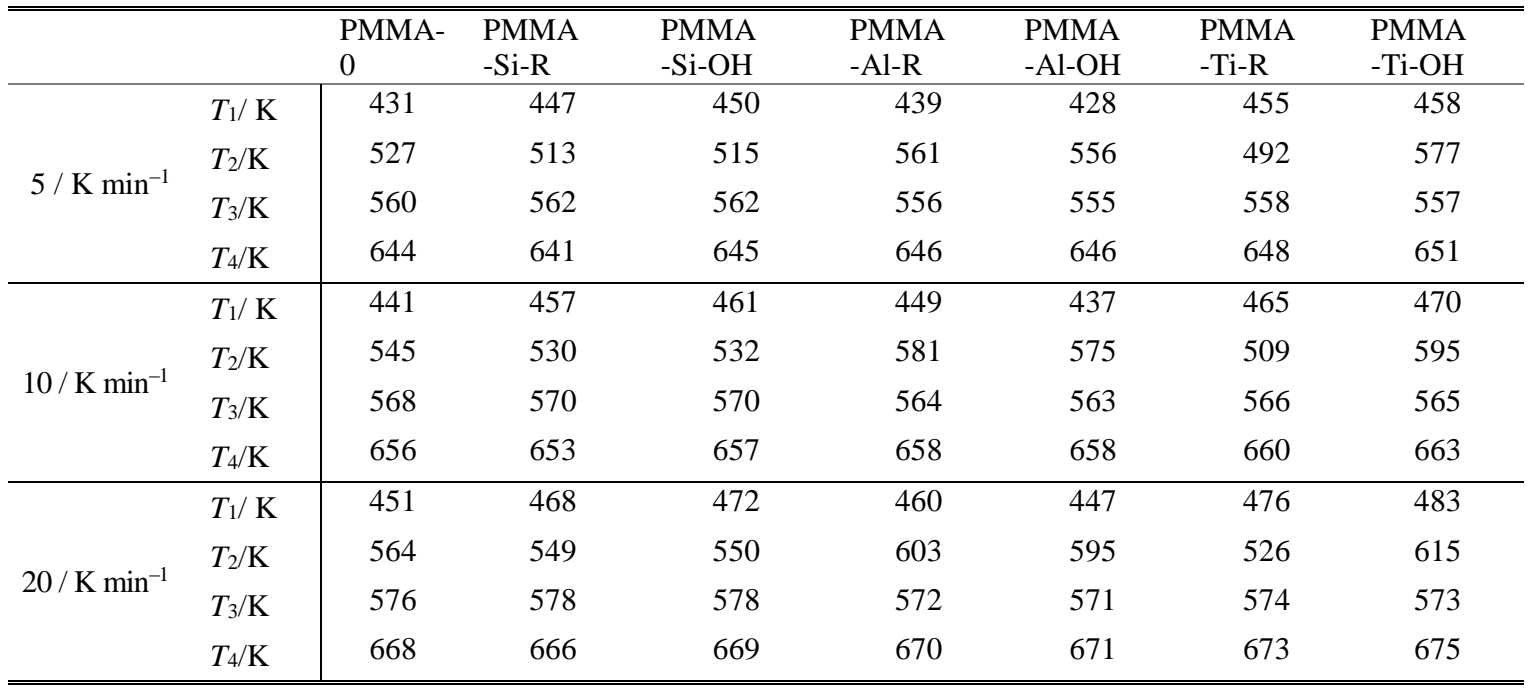

On the basis of data given in Table 2, it can be noticed that the type and nature of nanoparticles affect the thermal stability and the degradation process mechanism. The addition of filler improves the thermal stability (assigned to the first DTG onset) of PMMA except for PMMA-Al-OH. The significant shift of the onset temperatures to higher values compared to pure PMMA is registered: $16 \mathrm{~K}$ for PMMA-Si-R; $19 \mathrm{~K}$ for PMMA-Si$\mathrm{OH}$; $24 \mathrm{~K}$ for PMMA-Ti-R; and $27 \mathrm{~K}$ for PMMATi-OH. The registered highest enhancement of thermal stability of PMMA nanocomposite by addition of hydrophilic titania (Aeroxide PF2) might be explained by the presence of iron oxide in the composition of the filler used. This acts as barrier and retards the heat and mass transport needed for the degradation process $[6,29]$. The hydrophilic $\mathrm{SiO}_{2}$ nanoparticles did not cause significant differences in the enhancement of the thermal stability of the prepared nanocomposites. Apparently there is an absence of any specific interaction that might affect the chain decomposition and insufficient hydrogen bonding interaction between carbonyl groups of PMMA and silanol groups of silica [12, 30]. The smallest impact on thermal stability of PMMA hybrids was found in the samples filled with alumina. Namely, the onset temperature of PMMA with hydrophobic $\mathrm{Al}_{2} \mathrm{O}_{3}$ was increased only by $8 \mathrm{~K}\left(T_{\text {onset }}=449 \mathrm{~K}\right)$, while $T_{\text {onset }}$ of PMMA with hydrophilic $\mathrm{Al}_{2} \mathrm{O}_{3}$ registered at an even lower temperature $\left(T_{\text {onset }}=437 \mathrm{~K}\right)$ in regard to pristine PMMA. The negligible influence of alumina and even the reduction of thermal stability of PMMA composites (decrease of the first DTG step temper- ature) might be due to oxygen adsorption by the metal oxide surface which caused a decrease of the free oxygen content in prepared PMMA/alumina nanosystems, leading to fewer peroxide bonds in the prepared hybrid materials $[6,31]$. The significant increase of DTG maxima of PMMA nanocomposites, assigned to head-to-head $\mathrm{H}-\mathrm{H}$ bonding, by addition of alumina and titania confirms the enhancement of head-to-head hydrogen bonding strength in PMMA chains. This is not the case for PMMA/silica nanocomposites, where the presence of hydrophilic $\mathrm{SiO}_{2}$ affected a decrease of DTG maxima connected to head-to-head H-H bonding by about $13 \mathrm{~K}$ compared to neat PMMA.

In order to obtain detailed information on the influence of nanoparticles type and nature on the thermal degradation mechanism and kinetics of the synthesized PMMA materials, the experimental TG data were transformed to mass conversion, $\alpha$, (obtained by applying eq. 1) and the corresponding $\mathrm{d} \alpha$ values at all three heating rates:

$$
\alpha=1-\frac{m_{t}-m_{\infty}}{m_{0}-m_{\infty}}
$$

The values of $\mathrm{d} \alpha$ versus temperature, obtained at three different heating rates $(5,10$ and 20 $\mathrm{K} / \mathrm{min}$ ) for pure PMMA and the sample containing $1 \mathrm{vol} \%$ of Aerosil $380 \mathrm{SiO}_{2}$ particles (PMMA-Si$\mathrm{OH})$ are shown in Figure 3.

As expected, the onset temperatures as well as DTG maxima in Figure 3 are shifted to higher values by the increasing heating rate from 5 to $20 \mathrm{~K} / \mathrm{min}[28,32]$. 

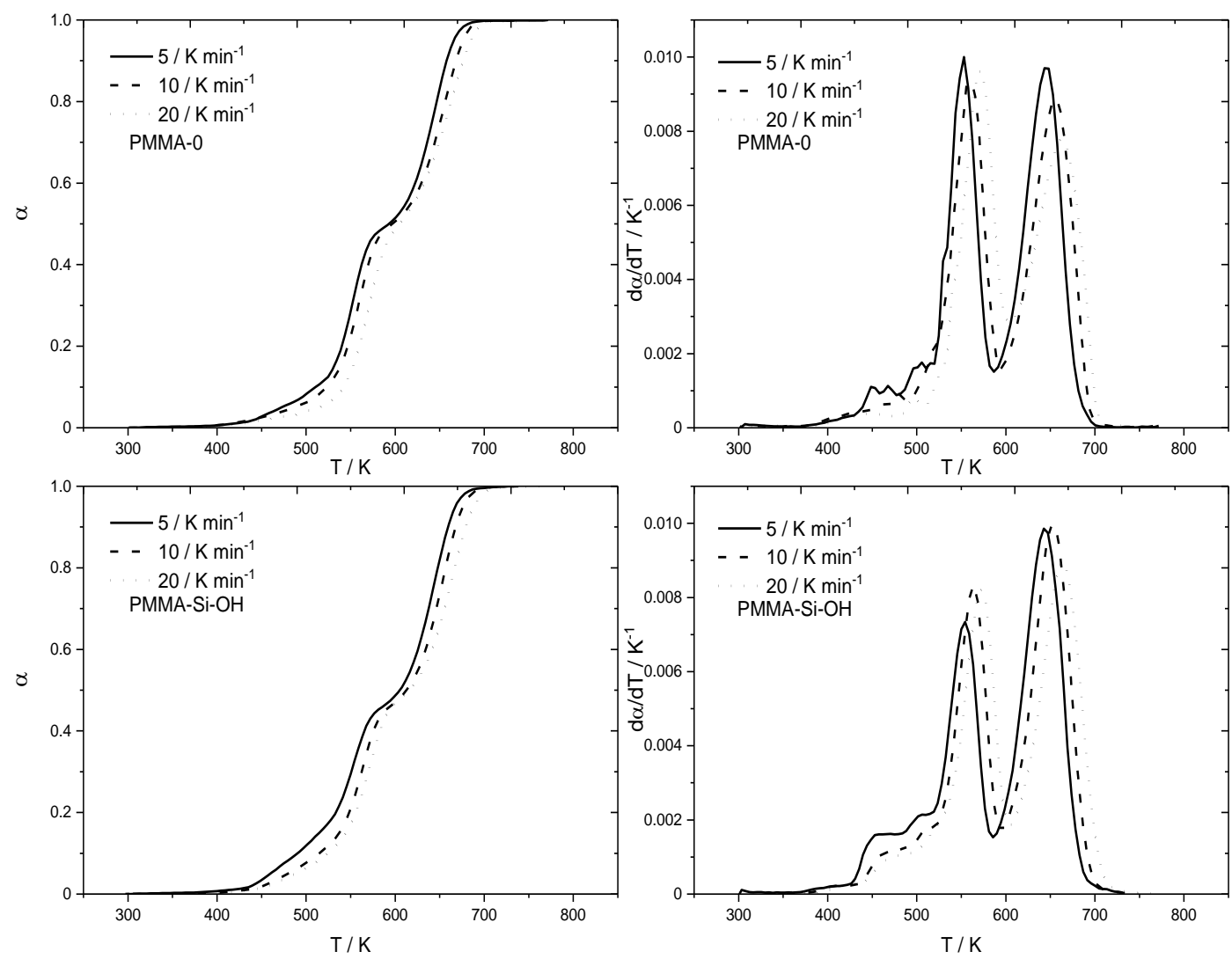

Fig. 3. The dependence of $\alpha$ and $\mathrm{d} \alpha$ on temperature obtained at three different heating rates for pure PMMA and the sample containing $1 \mathrm{vol} \%$ of Aerosil $380 \mathrm{SiO}_{2}$ particles (PMMA-Si-OH)

The main goal of the work was focused on selecting an appropriate mathematical model which would well describe the thermal degradation of unfilled and filled PMMA and on investigating the influence from the addition of nanoparticles. For this purpose, the experimental data were fitted with following equations [33]:

$$
\frac{\mathrm{d} \alpha}{\mathrm{d} t}=A e^{-\frac{E a}{R T}}(1-\alpha)^{n},
$$

where $\mathrm{d} \alpha / \mathrm{d} t$ is the reaction rate, $E_{a}$ is the activation energy, $A$ is the pre-exponential factor, and $n$ is the reaction order. If one assumes that $\beta$ is a heating rate constant and substitutes $\mathrm{d} T=\beta \mathrm{d} t$ into eq. (2), one obtains:

$$
\frac{\mathrm{d} \alpha}{\mathrm{d} T}=\frac{A}{\beta} e^{-\frac{E a}{R T}}(1-\alpha)^{n} .
$$

This can be described after integration by following equations:

$$
\begin{gathered}
\int_{0}^{\alpha} \frac{\mathrm{d} \alpha}{(1-\alpha)^{n}}=\frac{A}{\beta} \int_{T_{0}}^{T} e^{-\frac{E a}{R T}} \mathrm{~d} T= \\
=\frac{A E a}{\beta R}\left\{-\frac{e^{x}}{x}+\int_{-\infty}^{x} \frac{e^{x}}{x} \mathrm{~d} x\right\}=\frac{A E a}{\beta R} l(x) .
\end{gathered}
$$

where $x=-E a /(R T) . T_{\mathrm{o}}$ is assumed low enough to be neglected. The unit for $\beta$ is in $\mathrm{K} \mathrm{min}^{-1}$ and the pre-exponential factor $A$ is in $\min ^{-1}$. If $n=1$, then the equation takes the following form:

$$
\ln (1-\alpha)=-\frac{A E a}{\beta R} l(x) .
$$

In order to calculate $l(x)$ form, Lyon's approximation is used[34]:

$$
l(x)=\frac{e^{x}}{x(x-2)},
$$

assuming four independent decomposition steps (see Figs. 1 and 2). Therefore, the final fitting equation that combines Eqs. 5 and 6 is described by the following form:

$$
\alpha=\sum_{i=1}^{4} p_{i}\left(1-e^{-\frac{A_{i} R T^{2} e^{-\frac{E a_{i}}{R T}}}{\beta\left(E a_{i}+2 R T\right)}}\right)
$$

subject to the constraint

$$
\sum_{i=1}^{4} p_{i}=1 .
$$

In Eq. (7), $p_{\mathrm{i}}$ represents the yield coefficient (contribution) of the $i^{\text {th }}$ mass loss stage. 
The unknown parameters in Eq. (7) that have to be found by fitting TG data for all four decomposition steps are the following: preexponential factors $\left(A_{1}, A_{2}, A_{3}, A_{4}\right)$, activation energies $\left(E_{\mathrm{a} 1}, E_{\mathrm{a} 2}, E_{\mathrm{a} 3}, E_{\mathrm{a} 4}\right)$, and yield coefficients $\left(p_{1}\right.$, $\left.p_{2}, p_{3}, p_{4}\right)$. Fifteen of the required sixteen parameters have to be determined in order to apply Eq. (8). The unknown parameters are found by minimizing the following function:

$$
\operatorname{Minimize}\left(F\left(p_{i}, E a_{i}, A_{i}\right)\right)=\sum_{\beta} \sum_{j=1}^{N}\left(\alpha_{\beta, j}-\sum_{i=1}^{4} p_{i}\left(1-e^{-\frac{A_{i} R T_{\beta, j}^{2} e^{-\frac{E a_{i}}{R T_{\beta, j}}}}{\left.\beta E a_{i}+2 R T_{\beta, j}\right)}}\right)\right)^{2}
$$

where $\beta$ denotes the heating rate $(5,10,20 \mathrm{~K} / \mathrm{min})$, $I=1 \ldots 4$ and $j=1 \ldots N . N$ represents the number of the experimental data. The minimization of the $F$ $\left(p_{i}, E a_{i}, A_{i}\right)$ in the respect of the sum of the heating rates $(\beta=5,10,20)$ was carried out with the Levenberg-Marquardt non-linear fitting algorithm. The novel modeling approach presented includes all three heating rates in one minimizing function. In this way, unique kinetic parameters (activation energy), regardless the heating rate, can be calculated.

The results of the calculations for all PMMA samples are shown in Table 3. The coefficients of correlation $\left(R^{2}\right)$ are very high, effectively ascend to 1 , while the residual mean squared errors (RMSE) diminish toward 0 , indicating a good accuracy of the proposed mathematical model. Figures 4 and 5 present the fit of experimentally obtained conversion data $(\alpha)$ and derivative conversion $(\mathrm{d} \alpha / \mathrm{d} t)$ de- pendences on temperature for the PMMA- 0 obtained at different heating rates $(\beta=5,10,20)$. It can be seen in Figure 3 that the proposed mathematical model described experimental TG data very well for all heating rates. On the other hand, DTG model curves did not match all of the experimental points (Fig. 4). This lack of correlation was expected, because DTG curves were not directly fitted and the DTG points were obtained using sensitive numerical differentiation of the TG experimental data. However, despite the differentiation error, the applied model successfully described DTG data as well.

Figure 6 presents the contribution of the individual processes, calculated using the proposed mathematical model, to the experimentally obtained TG/DTG data. The calculated contributions ( $p$ ) for other PMMA nanocomposites are summarized in Table 3.
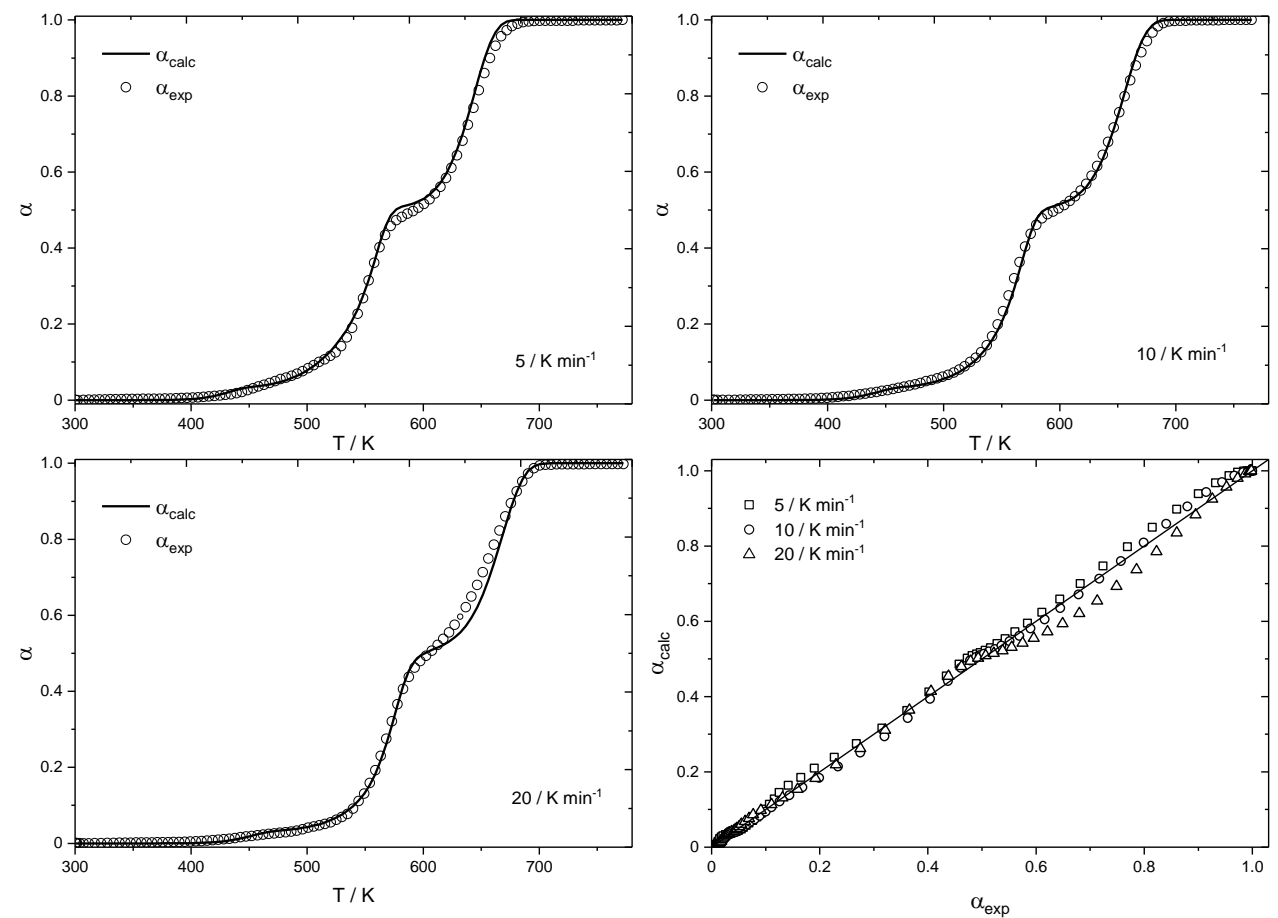

Fig. 4. The comparison between experimental and fitted mass conversion, $\alpha$, versus temperature, obtained at three heating rates, for pure PMMA (sample code PMMA-0) 

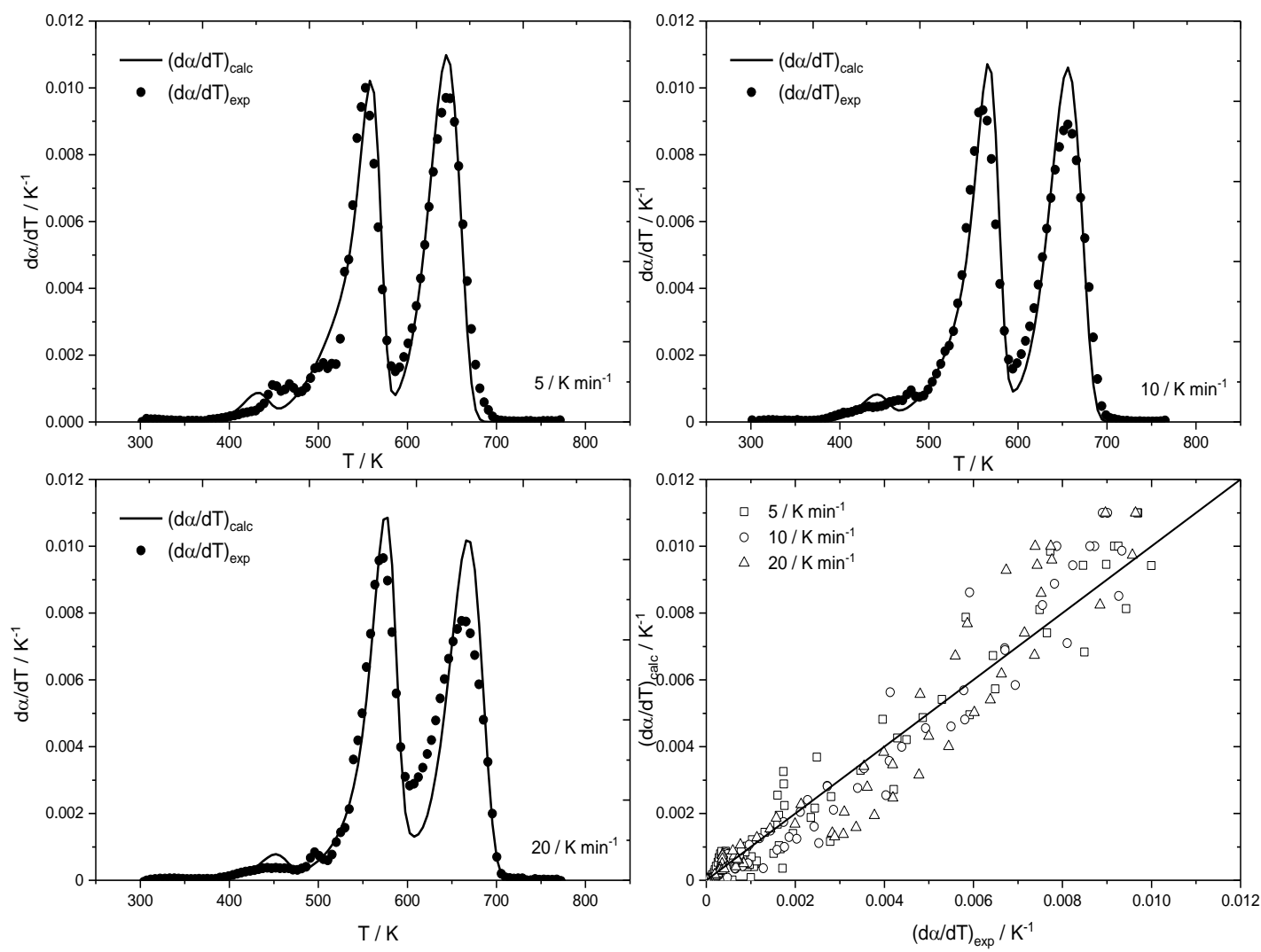

Fig. 5. The comparison between derivative and fitted derivative mass conversion, $d \alpha / d T$, versus temperature, obtained at three heating rates, for pure PMMA (sample code PMMA-0).
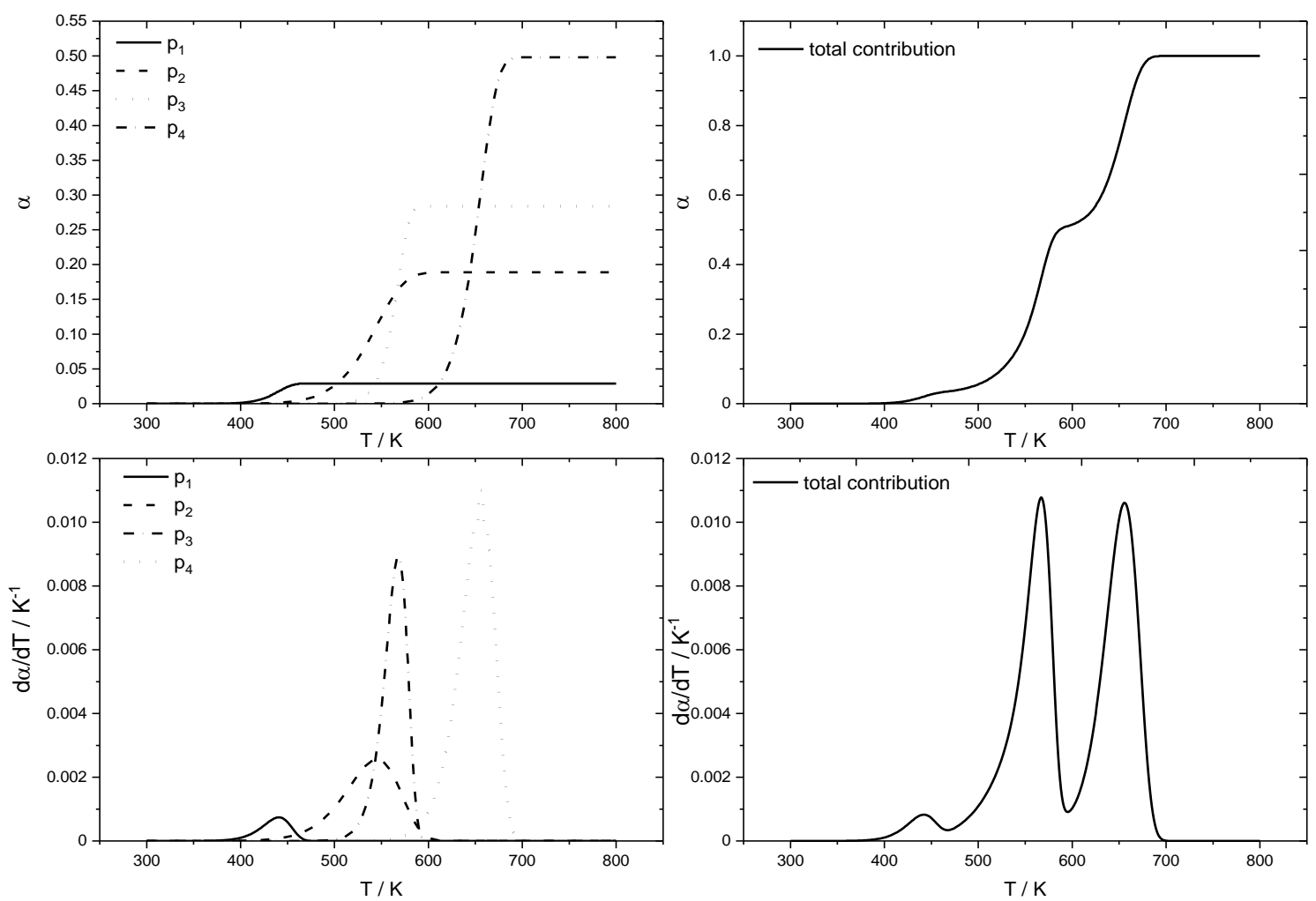

Fig. 6. The contribution of the calculated individual processes to the experimentally determined TG/DTG data 
T a ble 3

Values of the fitting parameters for all PMMA samples and the fitting quality

\begin{tabular}{|c|c|c|c|c|c|c|c|}
\hline & PMMA-0 & $\begin{array}{c}\text { PMMA } \\
\text {-Si-R }\end{array}$ & $\begin{array}{l}\text { PMMA } \\
\text {-Si-OH }\end{array}$ & $\begin{array}{c}\text { PMMA } \\
\text {-Al-R }\end{array}$ & $\begin{array}{l}\text { PMMA } \\
\text {-Al-OH }\end{array}$ & $\begin{array}{c}\text { PMMA } \\
\text {-Ti-R }\end{array}$ & $\begin{array}{l}\text { PMMA } \\
\text {-Ti-OH }\end{array}$ \\
\hline$p_{1}$ & 0.029 & 0.038 & 0.045 & 0.025 & 0.022 & 0.072 & 0.057 \\
\hline $\log \left(A_{1}\right)$ & 12.17 & 12.31 & 11.68 & 12.24 & 12.31 & 12.33 & 10.52 \\
\hline $\begin{array}{l}E a_{1} \\
\left(\mathrm{~kJ} \mathrm{~mol}^{-1}\right)\end{array}$ & 104.29 & 109.54 & 105.02 & 106.94 & 104.52 & 111.66 & 97 \\
\hline$p_{2}$ & 0.189 & 0.131 & 0.165 & 0.223 & 0.188 & 0.034 & 0.092 \\
\hline $\log \left(A_{2}\right)$ & 7.48 & 7.53 & 7.64 & 7.03 & 7.54 & 7.55 & 8.01 \\
\hline $\begin{array}{l}E a_{2} \\
\left(\mathrm{~kJ} \mathrm{~mol}^{-1}\right)\end{array}$ & 82.99 & 81.07 & 82.40 & 83.97 & 88.35 & 77.82 & 96.75 \\
\hline$p_{3}$ & 0.284 & 0.250 & 0.258 & 0.231 & 0.299 & 0.287 & 0.300 \\
\hline $\log \left(A_{3}\right)$ & 20.16 & 20.64 & 20.11 & 20.54 & 20.62 & 20.61 & 20.75 \\
\hline $\begin{array}{l}E a_{3} \\
\left(\mathrm{~kJ} \mathrm{~mol}^{-1}\right)\end{array}$ & 220.17 & 225.14 & 220.30 & 222.41 & 222.96 & 224.16 & 226.02 \\
\hline$p_{4}$ & 0.498 & 0.581 & 0.532 & 0.521 & 0.490 & 0.608 & 0.551 \\
\hline $\log \left(A_{4}\right)$ & 15.43 & 14.96 & 15.13 & 15.27 & 15.01 & 15.16 & 15.38 \\
\hline $\begin{array}{l}E a_{4} \\
\left(\mathrm{~kJ} \mathrm{~mol}^{-1}\right)\end{array}$ & 196.92 & 190.45 & 193.52 & 195.70 & 192.48 & 195.00 & 198.38 \\
\hline \multicolumn{8}{|c|}{ Quality of the fitting function } \\
\hline $\mathrm{RMSE}_{5}$ & 0.0129 & 0.0133 & 0.0122 & 0.0111 & 0.0092 & 0.0102 & 0.0103 \\
\hline $\mathrm{RMSE}_{10}$ & 0.0090 & 0.0139 & 0.0085 & 0.0073 & 0.0069 & 0.0123 & 0.0048 \\
\hline $\mathrm{RMSE}_{20}$ & 0.0161 & 0.0104 & 0.0120 & 0.0069 & 0.0064 & 0.0145 & 0.0110 \\
\hline $\mathrm{R}^{2}{ }_{5}$ & 0.9994 & 0.9993 & 0.9994 & 0.9995 & 0.9997 & 0.9995 & 0.9996 \\
\hline $\mathrm{R}^{2}{ }_{10}$ & 0.9996 & 0.9989 & 0.9996 & 0.9997 & 0.9997 & 0.9993 & 0.9999 \\
\hline $\mathrm{R}^{2}{ }_{20}$ & 0.9985 & 0.9993 & 0.9992 & 0.9997 & 0.9998 & 0.9990 & 0.9994 \\
\hline RMSE $_{\text {tot. }}$ & 0.0130 & 0.0127 & 0.0110 & 0.0086 & 0.0076 & 0.0125 & 0.0091 \\
\hline $\mathrm{R}_{\text {tot. }}^{2}$ & 0.9990 & 0.9990 & 0.9992 & 0.9996 & 0.9997 & 0.9989 & 0.9995 \\
\hline
\end{tabular}

Figure 7 displays the influence of nanofiller on the activation energy of each thermal decomposition step. It can be seen that the activation energies of the first decomposition stage of prepared PMMA composites, connected to the degradation step initiated by radical transfer to the unsaturated chain ends or the unreacted MMA monomers trapped inside of the polymer, are higher for the samples containing 1 vol \% of hydrophobic nanofillers. The highest value of $E_{\mathrm{a}}(111.7 \mathrm{~kJ} / \mathrm{mol})$ is registered for PMMA with hydrophobic titania nanoparticles. On the basis of the previous discussion, it might be supposed that hydrophobic inorganic particles were trapped with chain ends. On the other hand, the opposite trend of nanofiller behavior for the second decomposition step is detected. The presence of hydrophilic nanoparticles improved $\mathrm{H}-\mathrm{H}$ bonding causing higher activation energies necessary for the scission. The highest value is determined for PMMA with hydrophilic titanium dioxide $(96.8 \mathrm{~kJ} / \mathrm{mol})$. These results are in the light of the origin of the second decomposition step which belongs to the homolytic scission of the chain due to $\mathrm{H}-\mathrm{H}$ bonding. Namely, the presence of hydrophilic nanoparticles improved $\mathrm{H}-\mathrm{H}$ bond- ing causing higher activation energies necessary for the scission. The trend for the impact of nanofillers on $E_{\mathrm{a} 3}$ and $E_{\mathrm{a} 4}$ is not clear.

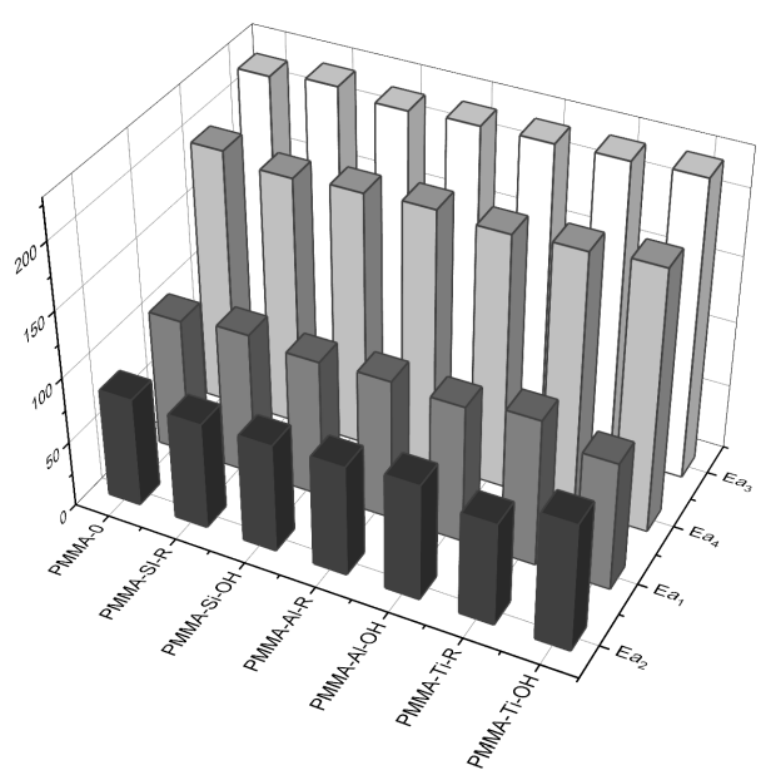

Fig. 7. The dependence of the activation energy of thermal decomposition steps on the nanoparticles type 
However, these decomposition steps, due to high temperature oxidation processes, are not of practical interest. From Figure 7, it can be concluded that the addition of the largest nanoparticles and the lowest BET surface $\left(\mathrm{TiO}_{2}\right)$, depending on their surface nature, caused the highest activation energy value of each decomposition stage of PMMA composites.

\section{CONCLUSIONS}

In order to investigate the influence of different inorganic nanofillers on the thermal stability of PMMA, silica, alumina and titania were introduced into the PMMA matrices. The thermal properties of PMMA nanocomposites containing silica and different metal oxide nanoparticles were studied by simultaneous TGA and DSC method (SDT). The detailed analysis of the thermogravimetric data of PMMA degradation and the influence of the nanoparticles on its thermal stability was carried out in order to help determine an adequate material design and the high-temperature interval for PMMA processing and application. The main goal of the work was focused on developing an appropriate mathematical model which accurately describes the thermal degradation kinetics of unfilled and filled PMMA. The novel modeling approach includes all three heating rates in one minimizing function, enabling the determination of unique kinetic parameters (activation energy) of each decomposition stage, regardless the heating rate. The suggested modeling approach correlated very well with all experimental data with a high coefficient of correlation $\left(R^{2}>0.99\right)$ and enabled the assessment of four DTG steps and determination of their individual contribution to the total mass loss. The highest activation energy of each decomposition stage was determined for PMMA filled with hydrophilic and hydrophobic $\mathrm{TiO}_{2}$ nanoparticles. The addition of alumina and titania enhanced the strength of significant head-to-head $\mathrm{H}-\mathrm{H}$ bonding. On the basis of DSC results, it was found that the glass transition temperature of prepared PMMA nanosystems is dependent on the size and nature of the nanooxide particles used. The highest $T_{\mathrm{g}}$ value was registered for the PMMA nanosystem with the largest hydrophilic particles (PMMA-Ti-OH).

Acknowledgement. The authors wish to thank for the financial support of the Ministry of Education, Science and Technological Development of the Republic of Serbia (Projects No. III45022 and No. ON172014).

\section{REFERENCES}

[1] A. Anžlovar, Z. C. Orel, M. Žigon, Poly(methyl methacrylate) composites prepared by in situ polymerization using organophillic nano-to-submicrometer zinc oxide particles, Eur. Polym. J., 46, 1216-1224 (2010). DOI: 10.1016/J.EURPOLYMJ.2010.03.010.

[2] H. Liu, H. Ye, T. Lin, T. Zhou, Synthesis and characterization of $\mathrm{PMMA} / \mathrm{Al}_{2} \mathrm{O}_{3}$ composite particles by in situ emulsion polymerization, Particuology, 6, 207-213 (2008). DOI: 10.1016/j.partic.2008.01.003.

[3] A. Schoth, C. Wagner, L. L. Hecht, S. Winzen, R. Muñoz-Espí, H. P. Schuchmann, K. Landfester, Structure control in PMMA/silica hybrid nanoparticles by surface functionalization, Colloid Polym. Sci., 292, 2427-2437 (2014). DOI: 10.1007/s00396-014-3316-7.

[4] S. N. Tripathi, P. Saini, D. Gupta, V. Choudhary, Electrical and mechanical properties of PMMA/reduced graphene oxide nanocomposites prepared via in situ polymerization, J. Mater. Sci., 48, 6223-6232 (2013). DOI: $10.1007 / \mathrm{s} 10853-013-7420-8$.

[5] H. Wang, P. Xu, W. Zhong, L. Shen, Q. Du, Transparent poly(methyl methacrylate)/silica/zirconia nanocomposites with excellent thermal stabilities, Polym. Degrad. Stab., 87, 319-32 (2005).

DOI: $10.1016 /$ j.polymdegradstab.2004.08.015.

[6] W. Viratyaporn, R. L. Lehman, Effect of nanoparticles on the thermal stability of PMMA nanocomposites prepared by in situ bulk polymerization, J. Therm. Anal. Calorim., 103, 267-273 (2011). DOI: $10.1007 / \mathrm{s} 10973-010-1051-y$.

[7] L.-H. Lee, W.-C. Chen, High-refractive-index thin films prepared from trialkoxysilane-capped poly(methyl methacrylate)-titania materials, Chem. Mater., 13, 1137-1142 (2001). DOI: $10.1021 / \mathrm{cm} 000937 \mathrm{z}$.

[8] F. A. Alzarrug, M. M. Dimitrijević, R. M. Jančić Heinemann, V. Radojević, D. B. Stojanović, P. S. Uskoković, R. Aleksić, The use of different alumina fillers for improvement of the mechanical properties of hybrid PMMA composites, Mater. Des., 86, 575-581 (2015). DOI: 10.1016/j.matdes.2015.07.069.

[9] A. Di Mauro, M. Cantarella, G. Nicotra, G. Pellegrino, A. Gulino, M.V. Brundo, V. Privitera, G. Impellizzeri, Novel synthesis of ZnO/PMMA nanocomposites for photocatalytic applications, Sci. Rep., 7, 40895 (2017). DOI: $10.1038 /$ srep40895.

[10] T. C. Chang, Y. T. Wang, Y. S. Hong, Y. S. Chiu, Organic-inorganic hybrid materials. V. Dynamics and degradation of poly(methyl methacrylate) silica hybrids, $J$. Polym. Sci. Part A, Polym. Chem. 38 (2000) 1972-1980. DOI: $\quad$ 10.1002/(SICI)1099-0518(20000601)38:11<1972:: AID-POLA60>3.0.CO;2-5.

[11] Z. H. Huang, K. Y. Qiu, The effects of interactions on the properties of acrylic polymers/silica hybrid materials prepared by the in situ sol-gel process, Polymer (Guildf), 38 (1997) 521-526.

DOI: 10.1016/S0032-3861(96)00561-7.

[12] Y. T. Wang, T. C. Chang, Y. S. Hong, H. B. Chen, Effect of the interfacial structure on the thermal stability of poly(methyl methacrylate)-silica hybrids, Thermochim. Acta. 397 (2003) 219-226. DOI:10.1016/S0040-6031(02)00327-1. 
[13] M. L. Saladino, T. E. Motaung, A. S. Luyt, A. Spinella, G. Nasillo, E. Caponetti, The effect of silica nanoparticles on the morphology, mechanical properties and thermal degradation kinetics of PMMA, Polym. Degrad. Stab., 97, 452-459 (2012).

DOI: 10.1016/j.polymdegradstab.2011.11.006.

[14] T. C. Chang, Y. T. Wang, Y. S. Hong, Y. S. Chiu, Effects of inorganic components on the structure and thermo-oxidative degradation of PMMA modified metal alkoxide-EAA complex, Thermochim. Acta., 390, 93102 (2002). DOI: 10.1016/S0040-6031(02)00078-3.

[15] A. Laachachi, M. Cochez, M. Ferriol, J. M. LopezCuesta, E. Leroy, Influence of $\mathrm{TiO}_{2}$ and $\mathrm{Fe}_{2} \mathrm{O}_{3}$ fillers on the thermal properties of poly(methyl methacrylate) (PMMA), Mater. Lett., 59 36-39 (2005).

DOI: 10.1016/j.matlet.2004.09.014.

[16] A. Laachachi, E. Leroy, M. Cochez, M. Ferriol, J. M. Lopez Cuesta, Use of oxide nanoparticles and organoclays to improve thermal stability and fire retardancy of poly(methyl methacrylate), Polym. Degrad. Stab., 89, (2005) 344-352.

DOI: 10.1016/j.polymdegradstab.2005.01.019.

[17] A. Laachachi, M. Ferriol, M. Cochez, J.-M. Lopez Cuesta, D. Ruch, A comparison of the role of boehmite $(\mathrm{AlOOH})$ and alumina $\left(\mathrm{Al}_{2} \mathrm{O}_{3}\right)$ in the thermal stability and flammability of poly(methyl methacrylate), Polym. Degrad. Stab., 94 1373-1378 (2009).

DOI: 10.1016/j.polymdegradstab.2009.05.014.

[18] J. E. Brown, T. Kashiwagi, Gas phase oxygen effect on chain scission and monomer content in bulk poly(methyl methacrylate) degraded by external thermal radiation, Polym. Degrad. Stab., 52, 1-10 (1996). DOI: $10.1016 / 0141-3910(95) 00213-8$.

[19] T. Fateh, F. Richard, T. Rogaume, P. Joseph, Experimental and modelling studies on the kinetics and mechanisms of thermal degradation of polymethyl methacrylate in nitrogen and air, J. Anal. Appl. Pyrolysis., 120, 423-433 (2016). DOI: 10.1016/j.jaap.2016.06.014.

[20] B. J. Holland, J. N. Hay, The kinetics and mechanisms of the thermal degradation of poly(methyl methacrylate) studied by thermal analysis-Fourier transform infrared spectroscopy, Polymer (Guildf)., 42, 4825-4835 (2001). DOI: $10.1016 / \mathrm{S} 0032-3861(00) 00923-X$.

[21] B. J. Holland, J. N. Hay, The value and limitations of non-isothermal kinetics in the study of polymer degradation, Thermochim. Acta., 388, 253-273 (2002). DOI: 10.1016/S0040-6031(02)00034-5.

[22] J. D. Peterson, S. Vyazovkin, C. A. Wight, Kinetic Study of stabilizing effect of oxygen on thermal degradation of poly(methyl methacrylate), J. Phys. Chem. B., 103, 8087-8092 (1999). DOI: 10.1021/jp991582d.
[23] O. Chiantore, M. P. Luda di Cortemiglia, M. Guaita, Changes of degree of polymerisation in the thermal degradation of poly(methyl methacrylate), Polym. Degrad. Stab., 24, 113-126 (1989).

DOI: 10.1016/0141-3910(89)90106-7.

[24] M. Ferriol, A. Gentilhomme, M. Cochez, N. Oget, J. L. Mieloszynski, Thermal degradation of poly(methyl methacrylate) (PMMA): modelling of DTG and TG curves, Polym. Degrad. Stab., 79, 271-281 (2003). DOI: 10.1016/S0141-3910(02)00291-4.

[25] L. E. Manring, D. Y. Sogah, G. M. Cohen, Thermal degradation of poly(methyl methacrylate). 3. Polymer with head-to-head linkages, Macromolecules, 22, 46524654 (1989). DOI: 10.1021/ma00202a048.

[26] O. Bera, M. Jovičić, J. Pavličević, B. Pilić, The influence of oxide nanoparticles on the kinetics of free radical methyl methacrylate polymerization in bulk, Polym. Compos., 34, 1342-1348 (2013). DOI: 10.1002/pc.22548.

[27] C. A. Wilkie, TGA/FTIR: an extremely useful technique for studying polymer degradation, Polym. Degrad. Stab., 66, 301-306 (1999). DOI: 10.1016/S0141-3910(99)00054-3.

[28] W. Tang, X.-G. Li, D. Yan, Thermal decomposition kinetics of thermotropic copolyesters made fromtrans-phydroxycinnamic acid and p-hydroxybenzoic acid, $J$. Appl. Polym. Sci., 91, 445-454 (2004). DOI: 10.1002/app.13103.

[29] J. Zhu, F. M. Uhl, A. B. Morgan, C. A. Wilkie, Studies on the Mechanism by Which the Formation of Nanocomposites Enhances Thermal Stability $\dagger$, Chem. Mater. 13, 4649-4654 (2001). DOI: 10.1021/cm010451y.

[30] R. R. Madathingal, S. L. Wunder, Thermal degradation of poly(methyl methacrylate) on $\mathrm{SiO}_{2}$ nanoparticles as a function of $\mathrm{SiO}_{2}$ size and silanol density, Thermochim. Acta., 526, 83-89 (2011). DOI: 10.1016/j.tca.2011.08.026.

[31] E. Džunuzović, M. Marinović-Cincović, J. Vuković, K. Jeremić, J. M. Nedeljković, Thermal properties of $\mathrm{PMMA} / \mathrm{TiO}_{2}$ nanocomposites prepared by in-situ bulk polymerization, Polym. Compos., 30, 737-742 (2009). DOI: $10.1002 / \mathrm{pc} .20606$.

[32] P. Paik, K. K. Kar, Kinetics of thermal degradation and estimation of lifetime for polypropylene particles: Effects of particle size, Polym. Degrad. Stab., 93, 24-35 (2008). DOI: 10.1016/j.polymdegradstab.2007.11.001.

[33] J. H. Flynn, L. A. Wall, General treatment of the thermogravimetry of polymers, J. Res. Natl. Bur. Stand. Sect. A Phys. Chem., 70A (1966) 487. DOI: 10.6028/jres.070A.043.

[34] R. E. Lyon, An integral method of nonisothermal kinetic analysis, Thermochim. Acta., 297, 117-124 (1997). DOI: 10.1016/S0040-6031(97)00158-5. 